\title{
PROTECTION BETWEEN STRAINS OF Papaya ringspot virus - TYPE W IN ZUCCHINI SQUASH INVOLVES COMPETITION FOR VIRAL REPLICATION SITES
}

\author{
Débora Maria Sansini Freitas ${ }^{1}$; Jorge Alberto Marques Rezende ${ }^{2 *}$ \\ ${ }^{1}$ USP/ESALQ - Programa de Pós-Graduação em Fitopatologia. \\ ${ }^{2}$ USP/ESALQ - Depto. de Entomologia, Fitopatologia e Zoologia Agrícola, C.P. 09 - 13418-900 - Piracicaba, SP - \\ Brasil. \\ *Corresponding author <jamrezen@esalq.usp.br>
}

\begin{abstract}
A mild strain of Papaya ringspot virus - type W (PRSV-W), named PRSV-W-1, has proved to be very effective in the control of the disease in zucchini squash plants under greenhouse and field conditions. The aim of this work was to obtain additional information on the protection mechanism between PRSV-W-1 and a severe homologous strain (PRSV-W-C) in Cucurbita pepo L. cv. Caserta. Protective inoculation with the mild strain was made on the cotyledons and the challenge inoculation with the severe strain was applied on the first true expanded leaf, and vice-versa. Plants were challenged at three, six or nine days later, respectively. Plants infected with either the mild or the severe strain alone served as controls. Evaluations were based on the recovery test and specific RTPCR to detect the challenge strain from challenge inoculated and newly developed leaves of the testplants. Symptoms evaluation was made 30 days after the challenge inoculation. Regardless of the site of the protective inoculation it seems there are some infectable sites available for superinfection with the severe strain. When the challenge inoculation was performed three days after the protective inoculation, a systemic superinfection occurred in some plants. All plants became protected against the expression of symptoms induced by the severe strain when the challenge inoculation was made six and nine days after protective inoculation. However, the severe strain was still detected in the inoculated and upper leaves of a few test-plants, eight days after the challenge inoculation. These data showed that competition for viral replication sites plays a role in the protection between strains of PRSV-W.
\end{abstract}

Key words: Cucurbita pepo, Potyvirus, cross protection, preimmunization

\section{PROTEÇÃO ENTRE ESTIRPES DO Papaya ringspot virus - TIPO W EMABOBRINHA DE MOITA ENVOLVE COMPETIÇÃO POR SÍTIOS DE REPLICAÇÃO VIRAL}

RESUMO: Uma estirpe fraca do vírus do mosaico da abobrinha (Papaya ringspot virus - type W), denominada PRSV-W-1, tem se mostrado altamente eficiente na proteção de algumas cucurbitáceas contra estirpes severas do vírus. O objetivo deste trabalho foi avaliar se a competição por sítios de replicação pode estar envolvida na proteção entre a estirpe PRSV-W-1 e a estirpe severa homóloga PRSV-W-C em plantas de abobrinha-de-moita (Cucurbita pepo L. cv. Caserta). Plantas inoculadas com a estirpe fraca na primeira folha verdadeira expandida foram desafiadas nos cotilédones e vice-versa. A inoculação de desafio com a estirpe PRSV-W-C foi feita aos três, seis ou nove dias após a inoculação de proteção. As plantas inoculadas separadamente com as duas estirpes serviram de controles. As avaliações da proteção foram feitas por meio do teste de recuperação da estirpe desafiante e detecção desta por RT-PCR, aos oito dias após o desafio. Avaliações de sintomas foram feitas 30 dias após o desafio. Os resultados mostraram que, independente do local onde foi realizada a inoculação de proteção, de uma maneira geral há alguns sítios livres para a superinfecção com a estirpe severa. Quando o desafio foi feito aos três dias, a estirpe severa se estabeleceu em algumas plantas que exibiram sintomas sistêmicos severos. Quando o desafio foi feito aos seis e nove dias após a proteção, nenhuma planta exibiu sintomas severos, porém a estirpe desafiante invadiu sistemicamente algumas plantas. Esses resultados mostram que a competição por sítios de replicação no local de infecção está envolvida na proteção entre estirpes do PRSV-W.

Palavras-chave: Cucurbita pepo, Potyvirus, proteção cruzada, preimunização 


\section{INTRODUCTION}

Papaya ringspot virus - type W (PRSV-W) is one of the most important viruses that may cause damage to zucchini squash (Cucurbita pepo L.) in Brazil and worldwide. This virus, responsible for the zucchini common mosaic, belongs to the family Potyviridae and has the shape of a cylindrical and flexuous filament, consisting of a single-stranded, positive RNA, with molecular weight of approximately $10.3 \mathrm{~kb}$. It is transmitted in the field in a non-persistent, non-circulative manner by several aphid species (Aphididae). It can also be transmitted by mechanical inoculation, but not via the seeds (Fauquet et al., 2005; Giampan \& Rezende, 2001; Purciful et al., 1996).

The PRSV-W symptoms in $C$. pepo consist of mosaic, presence of blisters and deformations on leaves, fruit malformation, with changed color, and plant stunting. This virus has been quite hard to be controlled in the field. The available sources of resistance have not yet been incorporated into all zucchini varieties, or the incorporated resistance is not complete to provide effective control of this disease. In addition, control by fighting the vectors or by cultural practices that minimize the incidence of this virus have proved to be ineffective. The use of preimmunized plants with mild strains of this virus, which do not affect yield and development and protect them against the effects of severe isolates in the field, has been investigated for over ten years in Brazil. Rezende et al. (1994), Rezende \& Pacheco (1998), Rezende et al. (1999), Dias \& Rezende (2000), and Rabelo \& Rezende (2004) showed that preimmunization was experimentally effective to control this virus disease in different species of cucurbits, with significant gains in production. Despite the promising results of this technique to control the common mosaic, there are no reports on the mechanism(s) that govern the protection provided by mild PRSV-W strains.

The objective of this study was to evaluate whether the competition for viral replication sites could be involved in the protection between mild and severe PRSV-W strains in zucchini squash plants.

\section{MATERIAL AND METHODS}

\section{Test plants}

Zucchini squash plants (C. pepo cv. Caserta) were grown in pots under greenhouse conditions in Piracicaba, SP, Brazil. Two plants were maintained per pot, and were frequently fertilized with small amounts of ammonium sulfate.

\section{Virus strains and inoculation}

A mild strain called PRSV-W-1, selected by Rezende et al. (1994), and a severe strain, PRSV-WC, from Campinas, SP, Brazil, were used. These strains were maintained separately on the 'Caserta' zucchini squash plants. The inocula of PRSV-W strains were separately prepared by grinding infected zucchini squash leaves at a rate of $1: 10(\mathrm{w} / \mathrm{vol})$ in $0.02 \mathrm{M}$ potassium phosphate buffer, $\mathrm{pH}$ 7.0, and $0.02 \mathrm{M}$ sodium sulfite, with a mortar and pestle. Cotyledonary leaves or partially expanded leaves were dusted with carborundum, and inoculation was performed by rubbing the leaf surface with the inoculum. The plants were later rinsed with water to remove excess abrasive and inoculum.

\section{Symptom ratings}

The test plants were evaluated by periodic readings of symptoms. The following symptom-severity rating scale was adopted: zero, for plants without symptoms; 1 , for plants with mild mosaic symptoms, without leaf deformations and with good development; 2 , for intermediate mosaic symptoms and little leaf deformation; and 3 for those exhibiting severe mosaic symptoms, intense leaf deformations and reduced development.

\section{Total RNA extraction and RT-PCR}

RT-PCR using a pair of specific primes developed by Della Vecchia et al. (2003) was used to detect the severe strain PRSV-W-C in some samples. Total RNA from zucchini plants was extracted with Trizol LS (Life Technologies), according to the manufacturer's protocol. First strand cDNAs for the coat protein $(\mathrm{CP})$ gene were synthesized from the total RNA extracted from infected plants with an antisense primer complementary to the $3^{\prime}$ ' end of the CP gene (5'AGCTAACCATGGGCGAGTATTCAGTTGCGC-3') (Souza Júnior, 1999). Three microliters of total RNA suspension were mixed with the antisense primer, diluted in distilled water previously treated with DEPC, at a concentration of 20 pmoles, $1 \mu \mathrm{L}$ of a $10 \mathrm{mM}$ dNTP mixture, and $5 \mu \mathrm{L}$ DEPC water. This solution was heated to $65^{\circ} \mathrm{C}$ for 5 minutes and was later maintained in ice for $1 \mathrm{~min}$. Next, $4 \mu \mathrm{L}$ of $5 \mathrm{X}$ buffer of the reverse transcriptase enzyme, $1 \mu \mathrm{L} 0.1 \mathrm{M}$ DTT (dithiotreitol), 200 units of the Superscript III enzyme, $4 \mu \mathrm{L}$ DEPC water, mixed in a final volume of $20 \mu \mathrm{L}$ were added. This solution was incubated at $25^{\circ} \mathrm{C}$ for 5 minutes, at $50^{\circ} \mathrm{C}$ for 60 minutes, and at $70^{\circ} \mathrm{C}$ for 15 minutes.

The cDNA was used in a Polymerase Chain Reaction (PCR). Thus, $2.5 \mu \mathrm{L}$ of the reaction product with the reverse transcriptase enzyme were mixed 
with $2.5 \mu \mathrm{L} 10 \mathrm{X}$ PCR buffer, $1.5 \mu \mathrm{L} \mathrm{MgSO}_{4} 50 \mathrm{mM}$, $0.5 \mu \mathrm{L}$ sense primer ('PS' 5'-AACTAGCACAAAAAC3'), specific for detection of the PRSV-W severe strain, 20 pmoles, $1 \mu \mathrm{L}$ antisense primer 20 pmols, 0.5 $\mu \mathrm{L}$ of dNTP mixture $10 \mathrm{mM}$, and $16.25 \mu \mathrm{L}$ Milli Q water (Della Vecchia et al., 2003). The mixture was then incubated at $80^{\circ} \mathrm{C}$ for 2 minutes. After that period, 1 unit Taq DNA Polymerase was added. The thermocycler regime (MJ Research PTC 200) consisted of one cycle at $94^{\circ} \mathrm{C}$ for 30 seconds, followed by $60^{\circ} \mathrm{C}$ for 30 seconds and $72^{\circ} \mathrm{C}$ for 1 minute. In the second cycle, temperatures were $94^{\circ} \mathrm{C}$ for 30 seconds, $57^{\circ} \mathrm{C}$ for 30 seconds, and 1 minute at $72^{\circ} \mathrm{C}$. The third cycle was at $94^{\circ} \mathrm{C}$ for 30 seconds, $53^{\circ} \mathrm{C}$ for $30 \mathrm{sec}-$ onds, and 1 minute at $72^{\circ} \mathrm{C}$, repeated 29 times and finished at $72^{\circ} \mathrm{C}$ for 7 minutes. The RT-PCR product was visualized in agarose gel at $1 \%$, containing $7 \mathrm{~mL}$ SYBR Safe ${ }^{\text {TM }}$ DNA Gel Stain in 0.5X TBE (45 mM Tris-borate, 1 mM EDTA, $\mathrm{pH}$ 8.3).

\section{Evaluation of competition for replication sites be- tween PRSV-W strains}

To evaluate the competition of the severe strain with the mild strain for replication sites, plants with approximately eight days after germination, containing the cotyledonary leaves and the first true leaf partially expanded, were used. The protective inoculation with the mild strain PRSV-W-1 was made in the cotyledonary leaves or in the first partially expanded true leaf. The cotyledon-protected plants were challenged with the severe strain PRSV-W-C in a young leaf after later development. Plants protected in the partially-expanded first true leaf were challenged in the cotyledonary leaves. The term challenge, or challenge inoculation, should be understood as the inoculation of a second strain, generally the severe strain, into plants previously infected with a mild strain of the same virus. Plants inoculated exclusively with the mild strain and initially healthy plants later inoculated with the severe strain at the time of the various challenge inoculations were used as controls.

The challenges were made by mechanical inoculation at three, six, or nine days after the protective inoculation, in distinct groups of plants. Evaluations were made as follows: eight days after challenging, leaf discs were collected from the tissues where challenge inoculations were made and from young leaves after later development of the plants. One half of each sample was used for total RNA extraction and RT-PCR analysis with the specific pair of primers for detection of the PRSV-W severe strain (Della Vecchia et al., 2003). The other half was used to prepare inocula for the challenging-strain recovery test. The extracted inocula were inoculated separately into two zucchini squash plants at the cotyledonary stage. The development of severe symptoms in those plants, approximately 30 days after inoculation, was an indication of the recovery of the PRSV-W-C used as challenger strain. The test plants in the protection assay were also observed for 30 days after challenging and evaluated for severity of leaf symptoms.

\section{RESULTS AND DISCUSSION}

Although pre-inoculation with mild strains is a technique known for several years with successful commercial application in some cases, little is known about the protection mechanism(s), even though this theme has been the object of several studies and speculations. Many theories have been proposed to explain them, but proper experiments to test some of them have never been carried out (Fulton, 1986; Ponz \& Bruening, 1986; Rezende \& Muller, 1995; Sherwood, 1987; Urban et al., 1989). Among the proposed theories are the following: a) formation of protection substances, similar to the antibodies produced in animals (Thung, 1931 apud Hiatt et al.,1989); b) adsorption of particles of the second virus, after they have penetrated the cells already occupied by the protective virus (Kanavau, 1949); c) competition for precursors or replication sites (Bawden \& Kassanis, 1945; Kunkel, 1934; Ponz \& Bruening, 1986; Ross, 1974); d) theories involving the coat protein (Costa, 1975; De Zoeten \& Fulton, 1975; Horikoshi et al.,1987; Sherwood \& Fulton, 1982); e) capture of the negative nucleic acid strand of the second virus, by the positive and abundant strand of the protector virus, which would be valid only for single-stranded RNA viruses, with positive sense or viroids (Palukatis \& Zaitlin, 1984), f) inhibition of the systemic movement of the second virus (Doods et al., 1985, Rezende et al., 1992), and g) gene silencing (Covey et al., 1997; Lindbo \& Dougherty, 2005; Ratcliff et al.,1999).

In this study it was proposed to evaluate competition of the PRSV-W-C severe strain for replication sites in plants previously infected with mild strain PRSV-W-1, as a potential protection mechanism. To accomplish this, it was initially necessary to study the systemic movement of the PRSV-W, starting from different inoculation points, to identify possible virus-free sites. The results of different tests conducted with the severe strain PRSV-W-C indicated that it was not detected in the cotyledonary leaves by the PTA-ELISA serologic test eight days after being inoculated into the first true, partially expanded leaf of the plants (data not presented). The fact that the virus was not detected in the cotyledonary leaves of test plants could be due to the absence of the virus, as intended to evaluate 
competition for replication sites as a protection mechanism, or because the PRSV-W-C concentration was below the level that can be detected by the serological test. Even then, in this case, it is supposed that this lower concentration could also be associated with the existence of some virus-free sites.

The possibility of existence of some virus-free sites in the cotyledonary leaves eight days after inoculation into the first partially expanded young leaf is supported by Roberts et al. (1997) who, in a very precise way, showed that the systemic movement of plant viruses in general follows the movement of photosynthesis products, obeying the source/sink transition. Since the cotyledonary leaves of zucchini squash plants have the dual function of providing storage substances and photoassimilates for plant development (Bisognin et al., 2004), it can be supposed that viral particles originating from replication of the virus inoculated into the plant's first partially expanded true leaf find it more difficult to reach the cotyledonary leaves, since they are functioning as a source, not as a sink. Therefore, the occupation of cells in cotyledonary tissues by the virus must be slower, consequently leaving some virus-free sites for a longer time.

The results of seven independent experiments to evaluate competition for replication sites as a possible mechanism involved in the protection between PRSV-W strains are presented jointly in Tables 1 and 2. When plants were inoculated with mild strain PRSV-W-1 in the cotyledonary leaves and challenged in young expanded leaves three days after the protective inoculation, only a single plant, among eleven, exhibited severe symptoms 30 days after challenge, indicating a breakdown on protection. When the protective inoculation was made in the first partially expanded true leaf and the challenge was made in the cotyledonary leaves, three plants exhibited severe mosaic symptoms after the same evaluation period (Table 1). Although few plants exhibited severe mosaic symptoms, indicating breakdown on protection, the recovery tests for the challenging strain indicated that it was capable of replicating and moving systemically in a higher number of plants, however without expressing symptoms, regardless of whether the protective inoculation was made in the cotyledonary leaves or in the partially expanded true leaf. In some cases, the presence of the severe strain was also confirmed by RT-PCR with the specific pair of primers (Table 2).

Using the same procedures, but challenging the plants six days after inoculation with the mild strain, a complete protection was obtained in terms of expression of the symptoms induced by the severe strain (Table 1). However, once again the severe strain could be retrieved and detected by RT-PCR, but in most cases only from the leaf where the challenge inoculation was made (Table 2). When the protective inoculation was made in the cotyledonary leaves and the challenge inoculation was made in the young leaf, the challenging severe strain could be recovered from the inoculation site, in three out of eleven plants. This strain, however, was not recovered from the leader shoot of any of these plants, eight days after challenging, although it was detected by RT-PCR in one of the eleven test-plants. On the other hand, when the protective inoculation was made in the first true partially expanded leaf and the challenge inoculation was made in the cotyledonary leaves, the severe strain was recovered from the cotyledonary leaves of eight among eleven test-plants. When the recovery test was made from the leader shoot tissue of these plants, eight days after challenging, the PRSV-W-C strain was only recovered from one plant, suggesting that its systemic invasion in the other plants seemed to have been blocked. The RT-PCR analysis confirmed the presence of the severe strain in some of these plants (Table 2).

Finally, when the challenge inoculation was performed nine days after the protective inoculation, once again complete protection was obtained against the manifestation of symptoms of the severe strain (Table 1). However, the severe strain could be recovered and detected by RT-PCR from the tissues of a few plants, from the sites where the challenge inoculations were made and from young leaves eight days after challenge inoculation (Table 2).

The results of assays to evaluate possible competition for replication sites as a protection mechanism between the mild and severe PRSV-W strains suggest that, regardless of the site where the protective inoculation is performed (cotyledonary leaf or first true partially expanded leaf), in general it seems that some sites are free for superinfection with the severe strain. When the severe strain was inoculated three days after protection, it became established in a few plants, moved systemically and prevailed over the mild strain as the plants exhibited severe symptoms. When challenge inoculation was made later (six and nine days after protective inoculation), all plants were protected against the expression of severe symptoms by the challenging strain. However, the challenging strain was capable of becoming established in the inoculated leaves and could even move systemically within a few plants. Because a recovery test was not performed 30 days after the challenge inoculation, it is difficult to know if the challenging strain was still present in the plant leader shoots. Nevertheless, results from two other protection tests involving the same strains, in which recovery tests were conducted 30 days after challenging, indicated that the severe strain was only recov- 
Table 1- Symptom ratings of zucchini squash plants cv. Caserta inoculated with mild strain PRSV-W-1 in the cotyledonary leaves and challenged with severe strain PRSV-W-C in young leaves and vice-versa.

\begin{tabular}{|c|c|c|c|c|c|c|}
\hline \multicolumn{2}{|c|}{ Inoculation } & \multirow{2}{*}{$\begin{array}{l}\text { Challenge after } \\
\text { protection (days) }\end{array}$} & \multirow{2}{*}{$\begin{array}{l}\text { Number of } \\
\text { tested plants }\end{array}$} & \multicolumn{3}{|c|}{$\begin{array}{c}\text { Number of plants according to } \\
\text { symptoms rating scale* }\end{array}$} \\
\hline Protection & Challenge & & & 1 & 2 & 3 \\
\hline Cotyledonary leaves & Young leaf & 3 & 11 & 10 & & 1 \\
\hline $1^{\text {st }}$ true leaf & $\begin{array}{l}\text { Cotyledonary } \\
\text { leaves }\end{array}$ & 3 & 11 & 8 & & 3 \\
\hline \multicolumn{2}{|c|}{ PRSV-W-C Control } & & 5 & & & 5 \\
\hline \multicolumn{2}{|c|}{ PRSV-W-1 Control } & & 3 & 3 & & \\
\hline Cotyledonary leaves & Young leaf & 6 & 11 & 11 & & \\
\hline $1^{\text {st }}$ true leaf & $\begin{array}{l}\text { Cotyledonary } \\
\text { leaves }\end{array}$ & 6 & 11 & 11 & & \\
\hline \multicolumn{2}{|c|}{ PRSV-W-C Control } & & 5 & & & 5 \\
\hline \multicolumn{2}{|c|}{ PRSV-W-1 Control } & & 2 & 2 & & \\
\hline Cotyledonary leaves & Young leaf & 9 & 11 & 11 & & \\
\hline $1^{\text {st }}$ true leaf & $\begin{array}{l}\text { Cotyledonary } \\
\text { leaves }\end{array}$ & 9 & 11 & 11 & & \\
\hline \multicolumn{2}{|c|}{ PRSV-W-C Control } & & 4 & & & 4 \\
\hline \multicolumn{2}{|c|}{ PRSV-W-1 Control } & & 4 & 4 & & \\
\hline
\end{tabular}

*Rating scale: rating zero, for plants without symptoms; 1 , for plants with mild mosaic symptoms, without leaf deformations and with good development; 2 , for intermediate mosaic symptoms and little leaf deformation; and 3 for those exhibiting severe mosaic symptoms, intense leaf deformations, and reduced development.

Table 2 - Severe strain (PRSV-W-C) detection from samples of tissues where superinoculations (challenges) were made and from leader shoots of test-plants indicated in table 1 by means of biological recovery and RT-PCR tests.

\begin{tabular}{|c|c|c|c|c|c|c|}
\hline \multicolumn{2}{|c|}{ Inoculation } & \multirow{2}{*}{$\begin{array}{l}\text { Challenge after } \\
\text { protection days }\end{array}$} & \multirow{2}{*}{$\begin{array}{l}\text { Number of } \\
\text { tested plants }\end{array}$} & \multirow{2}{*}{$\begin{array}{c}\text { Analyzed } \\
\text { Sample }\end{array}$} & \multirow{2}{*}{$\begin{array}{l}\text { Recovery test for } \\
\text { PRSV-W-C }\end{array}$} & \multirow{2}{*}{$\begin{array}{c}\text { RT-PCR } \\
\text { PRSV-W-C }\end{array}$} \\
\hline Protection & Challenge & & & & & \\
\hline \multirow[t]{2}{*}{ Cotyledonary leaves } & Young leaf & 3 & 11 & Challenge leaf & $6 / 11$ & $4 / 7$ \\
\hline & & & & Leader shoot & $4 / 11$ & $2 / 7$ \\
\hline \multirow[t]{2}{*}{$1^{\text {st }}$ true leaf } & Cotyledonary leaves & 3 & 11 & Challenge leaf $f^{(1)}$ & $6 / 9$ & $4 / 7$ \\
\hline & & & & Leader shoot & $4 / 11$ & $2 / 7$ \\
\hline \multicolumn{2}{|c|}{ PRSV-W-C Control } & & 5 & Leader shoot & $5 / 5$ & $5 / 5$ \\
\hline \multicolumn{2}{|c|}{ PRSV-W-1 Control } & & 3 & Leader shoot & $0 / 3$ & $0 / 3$ \\
\hline \multirow[t]{2}{*}{ Cotyledonary leaves } & Young leaf & 6 & 11 & Challenge leaf & $3 / 11$ & $0 / 6$ \\
\hline & & & & Leader shoot & $0 / 11$ & $1 / 6$ \\
\hline \multirow[t]{2}{*}{$1^{\text {st }}$ true leaf } & Cotyledonary leaves & 6 & 11 & Challenge leaf & $8 / 11$ & $3 / 6$ \\
\hline & & & & Leader shoot & $1 / 11$ & $1 / 6$ \\
\hline \multicolumn{2}{|c|}{ PRSV-W-C Control } & & 5 & Leader shoot & $5 / 5$ & $4 / 5$ \\
\hline \multicolumn{2}{|c|}{ PRSV-W-1 Control } & & 2 & Leader shoot & $0 / 2$ & $0 / 2$ \\
\hline \multirow[t]{2}{*}{ Cotyledonary leaves } & Young leaf & 9 & 11 & Challenge leaf & $3 / 11$ & $5 / 11$ \\
\hline & & & & Leader shoot & $3 / 11$ & $3 / 11$ \\
\hline \multirow[t]{2}{*}{$1^{\text {st }}$ true leaf } & Cotyledonary leaves & 9 & 11 & Challenge leaf & $2 / 11$ & $5 / 11$ \\
\hline & & & & Leader shoot & $2 / 11$ & $2 / 11$ \\
\hline \multicolumn{2}{|c|}{ PRSV-W-C Control } & & 4 & Leader shoot & $3 / 4$ & $4 / 4$ \\
\hline \multicolumn{2}{|c|}{ PRSV-W-1 Control } & & 4 & Leader shoot & $0 / 4$ & $0 / 4$ \\
\hline
\end{tabular}

${ }^{(1)}$ Cotyledonary leaf of one plant senesced before being collected. ${ }^{(2)}$ Symptom ratings higher than rating 2 indicate the presence of severe strain PRSV-W-C, while lower ratings indicate the presence of mild strain PRSV-W-1 only. 
ered from one among twenty plants (data not presented). This result is a strong indication that the severe PRSV-W strain could have been gradually eliminated with time in a process similar to gene silencing, as demonstrated by Ratcliff et al. (1999) to be one of the protection mechanisms between plant virus strains.

Novaes \& Rezende (2003) studied the protection of passion vines (Passiflora edulis f. flavicarpa Deg.) with six mild strains of Passion fruit woodiness virus (PWV) and verified a lack of protection when the plants were challenged with a severe strain of this virus (PWV-SP). Estimates of the concentrations of mild strains in several leaves of these plants by PTAELISA indicated they were not uniformly distributed in passion fruit vines. As a result, in regions where the mild strains were irregularly distributed or were found at low concentrations, there may be free sites for superinfection with the severe strain to occur; because the severe strain is more competitive, it later invades the plants systemically. This breakdown on protection, however, did not occur in studies with sunn hemp plants (Crotalaria juncea L.) infected with the same mild strains of PWV (Novaes \& Rezende, 2005). In this case, after analyzing the concentrations of mild strains in the plant tissues, the authors suggested that protection effectiveness was apparently associated with a more uniform concentration and distribution of mild strains in the tissues of this plant species.

The interaction between a plant species and protection between virus strains had already been reported by Rezende et al. (1992), who studied protection between serologically distinct Tobacco mosaic virus strains (TMV-C and TMV-P) in plants of Arabidopsis thaliana (L.) Heynh and Nicotiana tabacum L. cvs. Samsun and Xanthi. When A. thaliana plants infected with one of the strains was challenged with the homologous strain, the latter was detected in the inoculated leaves, but did not move systemically within the plants. On the other hand, when the protection test was conducted in N. tabacum cvs. Samsun and Xanthi plants, it was observed that in all plants where the challenging strain multiplied in the challenge inoculated site, it also moved systemically to the young leaves of the plants. Dodds et al. (1985) obtained similar results in protection studies involving tomato plants with a mild strain of the Cucumber mosaic virus, designated as CMV-P. When plants infected with this mild strain were challenged only with the RNA of a severe strain (CMV-S), the severe strain only multiplied at the inoculation site. For a few plants where systemic invasion of the severe strain occurred, the authors suggested that this was due to an incomplete invasion by the protective mild strain, which is an indication of competition for infection sites. They also suggested that the systemic movement of the virus within the plant should be similar for strains of the same virus. Consequently, the second virus would be prevented from exerting its own systemic invasion mechanism due to the saturation of sites within the cells or to changes of presumed receptors involved in initial cellto-cell or long-distance movements.

In the present work, competition for replication sites at the infection point is involved in the protection between PRSV-W strains, especially in the first few days after protective inoculation with the mild strain. Later on, there seems to exist some degradation mechanism of the severe strain, which could be of the gene silencing type, the confirmation of which depends on supplementary studies.

\section{ACKNOWLEDGMENTS}

To FAPESP for funding and thanks to Dr. Hugo Kuniyuki (APTA, IAC, Campinas, SP) for critically reading the manuscript.

\section{REFERENCES}

BAWDEN, F.C.; KASSANIS, B. The suppression of one plant virus by another. Annals of Applied Biology, v.32, p.52-7, 1945.

BISOGNIN, D.A.; AMARANTE C.V.T.; DELLAI, J. Contribuição das folhas cotiledonares para o crescimento e estabelecimento de plântulas de cucurbitáceas. Horticultura Brasileira, v.22, p.309-313, 2004.

COSTA, A.S. Proteção. In: Virologia vegetal. Piracicaba: USP/ ESALQ, 1975. 15p.

COVEY, S.N.; AL-KAFF, N.S.; LANGARE, A.; TURNER, D.S. Plants combat infection by gene silencing. Nature, v.385, p.781-782, 1997.

DELLA VECCHIA, M.G.S.; CAMARGO, L.E.A.; REZENDE, J.A.M. Nucleotide sequence comparison of the capsid protein gene of severe and protective mild strains of Papaya ringspot virus. Fitopatologia Brasileira, v.28, p.678-681, 2003.

DE ZOETEN, G.A.; FULTON, R.W. Understanding generates possibilities. Phytopathology, v.65, p.221-2, 1975.

DIAS, P.R.P.; REZENDE, J.A.M. Premunização da abóbora híbrida "Tetsukabuto" para o controle do mosaico causado pelo Papaya ringspot virus - type W. Summa Phytopathologica, v.26, p.390-398, 2000.

DODDS, J.A.; LEE, S.Q.; TIFFANY, M. Cross protection between strains of Cucumber mosaic virus; effect of host and type of inoculum on accumulation of virions and double-stranded RNA of the challenge strain. Virology, v.144, p.301-309, 1985.

FAUQUET, C.M.; MAYO, M.A.; MANILOFF, J.; DESSELBERGER, U.; BALL, L.A. (Ed.) Virus taxonomy: eighth report of the International Committee on Taxonomy of Viruses. San Diego: Elsevier Academic Press, 2005.1162p.

FULTON, R.W. Practices and precautions in the use of cross protection for plant virus disease control. Annual Review of Phytopathology, v.24, p.67-81, 1986.

GIAMPAN, J.S.; REZENDE, J.A.M. Transmissibilidade por afídeos e reação de diversas espécies vegetais às estirpes fracas premunizantes do PRSV-W. Summa Phytopathologica, v.27, p.279-283, 2001.

HIATT, A.; CAFFERKEY, R.; BOWDISH, K. Production of antibodies in transgenic plants. Nature, v.342, p.76-78, 1989. 
HORIKOSHI, M.; NAKAYAMA, M.; YMAOKA, N.; FUROSAWA, I.; SHISHIAMA, J. Brome mosaic virus coat protein inhibits viral RNA synthesis in vitro. Virology, v.158, p.15-19, 1987.

KANAVAU, J.L. On the correlation of the phenomena associated with chromosomes, foreign proteins and viruses. III. Virus associated phenomena, characteristics and reproduction. The American Naturalist, v.83, p.13-38, 1949.

KUNKEL, L.O. Studies on acquired immunity with tobacco and aucuba mosaics. Phytopathology, v.24, p.437-66, 1934.

LINDBO, J.A.; DOUGHERTY, W.G. Plant pathology and RNAi: a brief history. Annual Review of Phytopathology, v.43, p.191204, 2005.

NOVAES, Q.S.; REZENDE, J.A.M. Protection between strains of Passion fruit woodiness virus in sunnhemp. Fitopatologia Brasileira, v.30, p.307-311, 2005.

NOVAES, Q S; REZENDE, J.A.M. Selected mild strains of Passion fruit woodiness virus (PWV) fail to protect pre-immunized vines in Brazil. Scientia Agricola, v.60, p.699-708, 2003.

PALUKATIS, P.; ZAITLIN, M. A model to explain the cross protection phenomenon shown by plant virus and viroids. In: KOSUGe, T.; NESTER, E. W. (Ed.) Plant-microbe interactions: molecular and genetic perspectives. New York: Macmillan, 1984. p.420-429.

PONZ, F.; BRUENING, G. Mechanisms of resistence to plant viruses. Annual Review of Phytopathology, v.24, p.355-381, 1986.

PURCIFUL, D.E.; EDWARDSON, J.R.; HIEBERT, E.; GONSALVES, D. Papaya ringspot potyvirus. In: BRUNT, A.A.; CRABTREE, K.; DALLWITZ, M.J.; GIBBS, A.J., WATSON, L.; ZURCHER, E.J. (Ed.) Viruses of plants: descriptions and lists from the VIDE database. Wallingford: CABI, 1996. p.874877 .

RABELO, L.C.; REZENDE, J.A.M. Seleção de uma estirpe fraca do Zucchini yellow mosaic virus com potencial para uso na premunização. Summa Phytopathologica, v.30, p.340-345. 2004.

RATCLIFF, F.G.; MacFARLANE, S.A.; BAULCOMBE. Gene silencing without DNA: RNA: mediated cross protection between viruses. The Plant Cell, v.11, p.1207-1215. 1999.

REZENDE, J.A.M.; MÜLLER, G.W. Mecanismos de proteção entre vírus e controle de viroses de vegetais por premunização. Revisão Anual de Patologia de Plantas, v.3, p.185-226, 1995.
REZENDE, J.A.M.; PACHECO, D.A. Control of Papaya ringspot virus - type $\mathrm{W}$ in zucchini squash by cross protection in Brazil. Plant Disease, v.82, p.171-175, 1998.

REZENDE, J.A.M.; PACHECO, D.A.; IEMMA, A.F. Efeitos da premunização da abóbora "Menina Brasileira" com estirpes fracas do vírus do mosaico do mamoeiro - estirpe melancia. Pesquisa Agropecuária Brasileira, v.34, p.1481-1489, 1999.

REZENDE, J.A.M.; URBAN, L.; SHERWOOD, J.L.; MELCHER, U. Host effect of cross protection between two strains of Tobacco mosaic virus. Journal of Phytopathology, v.136, p.147-53, 1992.

REZENDE, J.A.M.; YUKI, V.A.; VEJA, J.; SCAGLIUSI, S.M.M.; BORBA, L.F. ; COSTA, A.S. Isolados fracos do potyvirus causador do mosaico da abobrinha presentes em bolhas atuam na premunização. Fitopatologia Brasileira, v.19, p.55-61, 1994.

ROBERTS, A.G.; SANTA CRUZ, S.; ROBERTS, I.M.; PRIOR, A.M.; TURGEON, R.; OPARKA, K.J. Phloem unloading in sink leaves of Nicotiana benthamiana: comparison of a fluorescent solute with a fluorescent virus. The Plant Cell, v.9, p.1381-1396, 1997.

ROSS, A.F. Interactions of viruses in the host. Acta Horticulturae, n.36, p.247-60, 1974.

SHERWOOD, J.L. Mechanisms of cross-protection between plant virus strains. In: EVERED, D.; HARNET, S. (Ed.) Plant resistance to viruses. Chichester: John Wiley, 1987. p.13650 .

SHERWOOD, J.L.; FULTON, R.W. The specific involvement of coat protein in Tobacco mosaic virus cross protection. Virology, v.119, p.150-158, 1982.

SOUZA JÚNIOR, M.T. Analysis of the resistance in genetically engineered papaya against Papaya ringspot potyvirus, partial characterization of the PRSV Brazil Bahia isolate, and development of transgenic papaya for Brazil. Ithaca: Cornell University, 1999. 277p. Thesis (PhD).

URBAN, L.A.; SHERWOOD, J.L.; REZENDE, J.A.M.; MELCHER, U. Examination of mechanisms of cross protection with nontransgenic plants. In: FRASER, R.S.S. (Ed.) Recognition and response in plant-virus interactions. New York: Springer, 1989. p.415-426.

Received May 14, 2007

Accepted October 01, 2007 